Jan Styczyński ${ }^{1 *}$, Robert Dębski ${ }^{*}{ }^{*}$, Anna Krenska ${ }^{1}$, Krzysztof Czyżewski ${ }^{1}$, Sylwia Kołtan ${ }^{1}$, Ninela Irga-Jaworska ${ }^{2}$, Magdalena Szalewska ${ }^{2}$, Maciej Niedźwiecki ${ }^{2}$, Joanna Stefanowicz ${ }^{2}$, Elżbieta Adamkiewicz-Drożyńska², Marcin Płonowski $^{3}$, Elżbieta Leszczyńska ${ }^{3}$, Maryna Krawczuk-Rybak ${ }^{3}$, Tomasz Ociepa ${ }^{4}$, Tomasz Urasiński ${ }^{4}$, Mariusz Wysocki $^{1}$

\title{
IMPROVEMENT OF CURE AFTER HEMATOPOIETIC STEM CELL TRANSPLANTATIONS IN CHILDREN
}

\section{WZROST WYLECZALNOŚCI PO TRANSPLANTACJI KOMÓREK HEMATOPOETYCZNYCH U DZIECI}

\footnotetext{
${ }^{1}$ Katedra Pediatrii, Hematologii i Onkologii, Collegium Medicum, Uniwersytet Mikołaja Kopernika, Bydgoszcz

${ }^{2}$ Katedra i Klinika Pediatrii, Hematologii i Onkologii, Uniwersytet Medyczny, Gdańsk

${ }^{3}$ Klinika Onkologii Dziecięcej, Uniwersytet Medyczny, Białystok

${ }^{4}$ Katedra i Klinika Pediatrii, Hematologii i Onkologii, Pomorski Uniwersytet Medyczny, Szczecin

(*) Both authors contributed equally to the study and are regarded as first authors
}

\section{S u m mary}

Badgond Hematopoietic stem cell transplantation (HSCT) is an established procedure for many acquired and congenital disorders of the hematopoietic system, including malignancies, bone marrow failure syndromes, disorders of the immune system, and metabolic disorders.

$\mathrm{Objective.} \mathrm{Analysis} \mathrm{of} \mathrm{results} \mathrm{of} \mathrm{hematopoietic}$ stem cell transplantations performed over a period of 12 years in a single pediatric center.

Patients and methods. All transplants performed between 2003 and 2015 in the Department of Pediatric Hematology and Oncology in Bydgoszcz were included in this analysis. The results of therapy with stem cell transplantation were analyzed in three time periods: 2004-2007, 2008-2011 and 2012-2015.

Results. A total number of transplants was 318 , including 132 auto-HSCT and 186 allo-HSCT. Among allogeneic transplants, 68 were done from matched-sibling donor and 118 from alternative donor. The mean survival for all patients estimated by Kaplan-Meier method was 8.1 years. Probability of overall survival (pOS) after all transplants was $0.64 \pm 0.03$. pOS after allo-HSCT was $0.62 \pm 0.04$, and $0.67 \pm 0.05$ after auto-HSCT. Overall survival for patients transplanted in the second (2008-2011) and third (20122015) time period was comparable both for auto- and alloHSCT. However, it was significantly higher than for patients transplanted in the first period of time (2004-2007) for all patients, and for those undergoing auto-HSCT. In allo-HSCT patients, in spite of increase of over $20 \%$ in pOS (43\% vs $66 \%$ vs $64 \%$ in respective time periods), the difference was not statistically significant.

Conclusion. Presented results of HSCT obtained in our center are comparable with those from other international registries and centers.

\section{Streszczenie}

W stęp. Transplantacja komórek krwiotwórczych (HSCT) jest ważną metodą terapeutyczną $\mathrm{w}$ wielu wrodzonych i nabytych chorobach, w tym nowotworowych, zespołach niewydolności szpiku oraz zaburzeniach immunologicznych i metabolicznych.

Cele m pracy jest analiza wyników HSCT w pojedynczym ośrodku pediatrycznym w okresie 12 lat. 
Pacjenci i metodyka. Analizie poddano wyniki przeszczepień wykonanych w latach 2003-2015 w Klinice Pediatrii, Hematologii i Onkologii w Bydgoszczy. Transplantacje analizowano w trzech przedziałach czasowych: 2004-2007, 2008-2011 oraz 2012-2015.

W y niki. Wykonano 318 HSCT, w tym 186 allogenicznych (68 zgodnych rodzinnych i 118 od dawców alternatywnych) oraz 132 autologiczne. Średnie przeżycie po HSCT, wyznaczone metodą Kaplana-Meiera wyniosło 8,1 lat. Całkowite prawdopodobieństwo przeżycia (pOS) wyniosło $0,64 \pm 0,03$; pOS po allo-HSCT wynosi $0,62 \pm 0,04$, a po auto-HSCT $0,67 \pm 0,05$. Nie wykazano znamiennych różnic w pOS zarówno po allo-HSCT, jak i po auto-HSCT pomiędzy drugim (2008-2011) i trzecim (2012-2015) analizowanym okresie. Jednakże, pOS było wyższe w drugim i trzecim okresie $\mathrm{w}$ stosunku do okresu pierwszego (2004-2007), zarówno dla wszystkich pacjentów, jak i u pacjentów po auto-HSCT. W grupie pacjentów allo-HSCT, uzyskano wzrost pOS o ponad $20 \%$ (43\% vs $66 \%$ vs $64 \%$ w kolejnych przedziałach czasu; ns).

W n i o s ki. Wyniki HSCT uzyskiwane aktualnie w naszym ośrodku są porównywalne $\mathrm{z}$ wynikami podawanymi w międzynarodowych rejestrach.

Key words: hematopoietic stem cells, high-dose therapy, stem cell transplantation, children, adolescents and young adults Słowa kluczowe: komórki krwiotwórcze, terapia wysokodawkowa, przeszczepianie komórek macierzystych, dzieci, młodzież i młodzi dorośli

\section{INTRODUCTION}

Hematopoietic stem cell transplantation (HSCT) is an established procedure for many acquired and congenital disorders of the hematopoietic system, including malignancies, bone marrow failure syndromes, disorders of the immune system, and metabolic disorders. By the end of 2012, more than 1 million transplants were done at 1516 transplant centers in total 75 countries performing HSCTs [1]. European Society for Blood and Marrow Transplantation (EBMT) is the largest HSCT society and registry worldwide, including 658 centers from 48 countries. A total number of 40829 HSCTs have been performed in EBMT centers in 2014, including $43 \%$ allogeneic and 57\% autologous transplants [2]. Up to 2015, over 517 thousands HSCTs were performed in all EBMT centers. According to a report from Poltransplant [3], the number of autologous and allogeneic transplantations performed in Poland in 2014 reached 873 and 572, respectively. In our Department we launched transplant program with matched sibling donor (MSD) allogeneic HSCT in 2003, autologous HSCT in 2004 and unrelated donor HSCT in allogeneic 2007.

The aim of this study is the analysis of results of hematopoietic stem cell transplantations performed over a period of 12 years in single pediatric center.

\section{METHODS}

All transplants performed between 2003 and 2015 in the Department of Pediatric Hematology and Oncology in Bydgoszcz were included in this analysis. The results of therapy with stem cell transplantation were analyzed in three time periods: 2004-2007, 20082011 and 2012-2015; all consecutive transplants were included into each time period. Since in 2003 only one allogeneic transplant was performed, this case was pooled with the first group. Patients underwent HSCT according to procedures described previously [4-7]. For GVHD prophylaxis, cyclosporine \pm methotrexate were used after transplants from peripheral blood (PB) or bone marrow (BM), and cyclosporine+steroids after cord blood transplants (CBT). The follow-up was censored on 29 February 2016.

Statistical analysis. Overall survival (OS) was set as the primary end point, and defined as time from transplantation to death or last follow-up. Probability of overall survival (pOS) was calculated using the Kaplan-Meier method and compared with the log-rank tests. Mean survival was also determined by KaplanMeier method, with $95 \%$ confidence interval (CI). Rate of survivors in the analyzed time periods was compared with chi-square test. All p-values are 2-tailed and considered statistically significant if the values were less than 0.05. All statistical analyses were performed using the SPSS22 software (SPSS Inc, Chicago, IL, USA).

\section{RESULTS}

Demographics. A total number of transplants performed between 2003 and 31 December 2015 was 318, including 132 auto-HSCT and 186 allo-HSCT. Among allogeneic transplants, 68 were done from MSD and 118 from alternative donor (including 3 haploidentical donor transplants). The recipients of transplants were males in 195 transplants and females 
in 123 cases. The median age of transplant recipients was 11.5 years (range 0.3-32 years). The source of hematopoietic stem cells was $\mathrm{PB}$ in 232 patients (73\%), BM in 83 patients $(26 \%)$ and $\mathrm{CB}$ in 3 patients $(0.9 \%)$. The median follow-up was 2.3 years (range: 0.1-12 years). The primary diagnosis were: acute lymphoblastic leukemia (ALL), acute myeloid leukemia and myelodysplastic syndromes (AML/MDS), chronic myeloid leukemia (CML), Hodgkin disease (HD), non-Hodgkin lymphoma (NHL), bone marrow failure (BMF/SAA), primary immunodeficiences (PID), brain tumors (CNS), neuroblastoma (NBL), Ewing tumor (ET), and other solid tumors (ST) (Table 1). In 284 cases, patients underwent one transplant, 27 patients had two transplants, 2 had three transplants and 1 had four transplants.

Table 1. Results of hematopoietic stem cell transplantation with respect to diagnosis and period of therapy

Tabela 1. Wyniki transplantacji komórek krwiotwórczych $w$ zależności od choroby podstawowej i okresu terapii

\begin{tabular}{|c|c|c|c|c|}
\hline \multirow[t]{2}{*}{$\begin{array}{l}\text { Diagnosis } \\
\text { Rozpoznanie }\end{array}$} & \multicolumn{3}{|c|}{$\begin{array}{c}\text { Probability of overall survival } \\
\text { Prawdopodobieństwo przeżycia }\end{array}$} & \multirow[t]{2}{*}{$\mathrm{p}$} \\
\hline & $2004-2007$ & $2008-2011$ & $2012-2015$ & \\
\hline $\begin{array}{l}\text { Acute Lymphoblastic } \\
\text { Leukemia }\end{array}$ & $\begin{array}{c}0.36 \pm 0.16 \\
(\mathrm{n}=10)\end{array}$ & $\begin{array}{c}0.67 \pm 0.08 \\
(\mathrm{n}=30)\end{array}$ & $\begin{array}{c}0.75 \pm 0.08 \\
(\mathrm{n}=27)\end{array}$ & 0.146 \\
\hline \begin{tabular}{|l} 
Acute \\
Leukemia \\
Myelodysplastic \\
Syndromes
\end{tabular} & $\begin{array}{l}0.71 \pm 0.17 \\
\quad(n=7)\end{array}$ & $\begin{array}{c}0.63 \pm 0.18 \\
(\mathrm{n}=31)\end{array}$ & $\begin{array}{c}0.52 \pm 0.10 \\
(\mathrm{n}=29)\end{array}$ & 0.427 \\
\hline $\begin{array}{|ll|}\text { Chronic } & \text { Myeloid } \\
\text { Leukemia } & \\
\end{array}$ & $\begin{array}{c}0.50 \pm 0.25 \\
(\mathrm{n}=4)\end{array}$ & $\begin{array}{c}0.67 \pm 0.27 \\
(\mathrm{n}=3)\end{array}$ & - & 0.538 \\
\hline Bone Marrow Failure & $\begin{array}{c}0.67 \pm 0.27 \\
(\mathrm{n}=3)\end{array}$ & $\begin{array}{c}0.90 \pm 0.09 \\
(\mathrm{n}=11)\end{array}$ & $\begin{array}{c}0.72 \pm 0.12 \\
(\mathrm{n}=15)\end{array}$ & 0.500 \\
\hline $\begin{array}{l}\text { Non-Hodgkin } \\
\text { Lymphoma }\end{array}$ & $\begin{array}{c}1.00 \pm 0.00 \\
(\mathrm{n}=1)\end{array}$ & $\begin{array}{c}1.00 \pm 0.00 \\
(\mathrm{n}=6)\end{array}$ & $\begin{array}{c}1.00 \pm 0.00 \\
(\mathrm{n}=7)\end{array}$ & 0.999 \\
\hline Hodgkin Lymphoma & $\begin{array}{c}0.87 \pm 0.11 \\
(\mathrm{n}=10)\end{array}$ & $\begin{array}{c}0.68 \pm 0.13 \\
(n=13)\end{array}$ & $\begin{array}{c}0.83 \pm 0.15 \\
(\mathrm{n}=6)\end{array}$ & 0.434 \\
\hline Neuroblastoma & $\begin{array}{c}0.45 \pm 0.13 \\
(\mathrm{n}=18)\end{array}$ & $\begin{array}{c}0.75 \pm 0.15 \\
(\mathrm{n}=8)\end{array}$ & $\begin{array}{c}0.83 \pm 0.11 \\
(\mathrm{n}=17)\end{array}$ & 0.143 \\
\hline Ewing Sarcoma & $\begin{array}{c}0.60 \pm 0.22 \\
(\mathrm{n}=5)\end{array}$ & $\begin{array}{c}0.23 \pm 0.19 \\
(\mathrm{n}=8)\end{array}$ & $\begin{array}{c}0.85 \pm 0.13 \\
(\mathrm{n}=7)\end{array}$ & 0.626 \\
\hline $\begin{array}{l}\text { Central Nervous } \\
\text { System tumors }\end{array}$ & $\begin{array}{c}0.20 \pm 0.12 \\
(\mathrm{n}=10)\end{array}$ & $\begin{array}{c}0.00 \pm 0.00 \\
(\mathrm{n}=1)\end{array}$ & $\begin{array}{c}1.00 \pm 0.00 \\
(\mathrm{n}=2)\end{array}$ & 0.316 \\
\hline Other solid tumors & $\begin{array}{c}0.25 \pm 0.21 \\
(\mathrm{n}=4)\end{array}$ & $\begin{array}{c}0.87 \pm 0.11 \\
(\mathrm{n}=8)\end{array}$ & $\begin{array}{c}1.00 \pm 0.00 \\
(\mathrm{n}=2)\end{array}$ & 0.016 \\
\hline \begin{tabular}{|l} 
Primary \\
Immunodeficiences
\end{tabular} & - & $\begin{array}{c}1.00 \pm 0.00 \\
(\mathrm{n}=2)\end{array}$ & $\begin{array}{c}0.75 \pm 0.15 \\
(\mathrm{n}=8)\end{array}$ & 0.464 \\
\hline
\end{tabular}

$\mathrm{n}$ - liczba pacjentów

Engraftment. The cumulative probabilities of neutrophil and platelet recovery were $95 \%$ and $88 \%$, respectively. The median time to neutrophil recovery (absolute neutrophil count, ANC>500) was 17 days (range, 1-34), while the median time to platelet engraftment (platelet count $>20 \mathrm{G} / \mathrm{L}$ ) was 16 days (range, 1-187).
Graft versus host disease (GVHD). The cumulative probabilities of acute GVHD (aGVHD) and extensive chronic GVHD (cGVHD) were $19.4 \%$ and $10.6 \%$, respectively. 36/186 (19.4\%) patients developed aGVHD grade II or higher, including 11 (5.9\%) with grade III or IV, while 14/132 (10.6\%) evaluable patients developed extensive cGVHD.

Mortality. A total of $218 / 318(68.6 \%)$ transplants were not associated with mortality at the time of this analysis. A hundred patients $(31.4 \%)$ died due to transplant-related complications $(n=45)$ or disease relapse/progression $(n=55)$. The cumulative probability of transplant related mortality (TRM) was $13.2 \%$ at one year: 31 patients $(9.7 \%)$ died within the first 100 days post-HCT, including 18 patients $(5.6 \%)$ who died before day 30 .

Overall survival. The mean survival for all patients estimated by Kaplan-Meier method was 8.1 years (95\%CI=7.4-8.7 years). Probability of overall survival (pOS) after all transplants was $0.64 \pm 0.03$ (Table 2); pOS after allo-HSCT was $0.62 \pm 0.04$, and $0.67 \pm 0.05$ after auto-HSCT. Overall survival for patients transplanted in the second (2008-2011) and third (2012-2015) time period was comparable both for auto- and allo-HSCT. However, it was significantly higher than for patients transplanted in the first period of time (2004-2007) for all patients, and for those undergoing auto-HSCT. In allo-HSCT patients, in spite of increase of over $20 \%$ in pOS $(43 \%$ vs $66 \%$ vs $64 \%$ in respective time periods), the difference was not statistically significant (Figure 1).

Table 2. Results of HSCT with respect to period of therapy Tabela 2. Wyniki transplantacji komórek krwiotwórczych w zależności od okresu terapii

\begin{tabular}{|l|c|c|c|c|c|}
\hline $\begin{array}{l}\text { Parameter } \\
\text { Parametr }\end{array}$ & $2004-2007$ & $2008-2011$ & $2012-2015$ & $\begin{array}{c}\text { Total } \\
\text { Razem }\end{array}$ & $\mathrm{p}$ \\
\hline $\begin{array}{l}\text { pOS (auto- } \\
\text { HSCT) }\end{array}$ & $\begin{array}{c}0,54 \pm 0,07 \\
(\mathrm{n}=54)\end{array}$ & $\begin{array}{c}0,79 \pm 0,07 \\
(\mathrm{n}=42)\end{array}$ & $\begin{array}{c}0,85 \pm 0,07 \\
(\mathrm{n}=36)\end{array}$ & $\begin{array}{c}0,67 \pm 0,05 \\
(\mathrm{n}=132)\end{array}$ & 0,006 \\
\hline $\begin{array}{l}\text { pOS (allo- } \\
\text { HSCT) }\end{array}$ & $\begin{array}{c}0,43 \pm 0,13 \\
(\mathrm{n}=20)\end{array}$ & $\begin{array}{c}0,66 \pm 0,05 \\
(\mathrm{n}=80)\end{array}$ & $\begin{array}{c}0,64 \pm 0,06 \\
(\mathrm{n}=85)\end{array}$ & $\begin{array}{c}0,62 \pm 0,04 \\
(\mathrm{n}=185)\end{array}$ & 0,284 \\
\hline pOS lącznie & $\begin{array}{c}0,51 \pm 0,06 \\
(\mathrm{n}=74)\end{array}$ & $\begin{array}{c}0,70 \pm 0,04 \\
(\mathrm{n}=122)\end{array}$ & $\begin{array}{c}0,70 \pm 0,05 \\
(\mathrm{n}=121)\end{array}$ & $\begin{array}{c}0,64 \pm 0,03 \\
(\mathrm{n}=317)\end{array}$ & 0,045 \\
\hline $\begin{array}{l}\text { Rate of } \\
\text { survivors }\end{array}$ & $\begin{array}{c}40 \\
(54,1 \%)\end{array}$ & $\begin{array}{c}88 \\
(72,1 \%)\end{array}$ & $\begin{array}{c}91 \\
(75,2 \%)\end{array}$ & $\begin{array}{c}219 \\
(69,1 \%)\end{array}$ & 0,005 \\
\hline
\end{tabular}

pOS - probability of overall survival; $\mathrm{n}$ - number of patients; HSCT - hematopoietic stem cell transplantation

\section{DISCUSSION}

Since 2003, when the transplant program was introduced in our department, we have developed therapeutic facility for children from Northern Poland, 

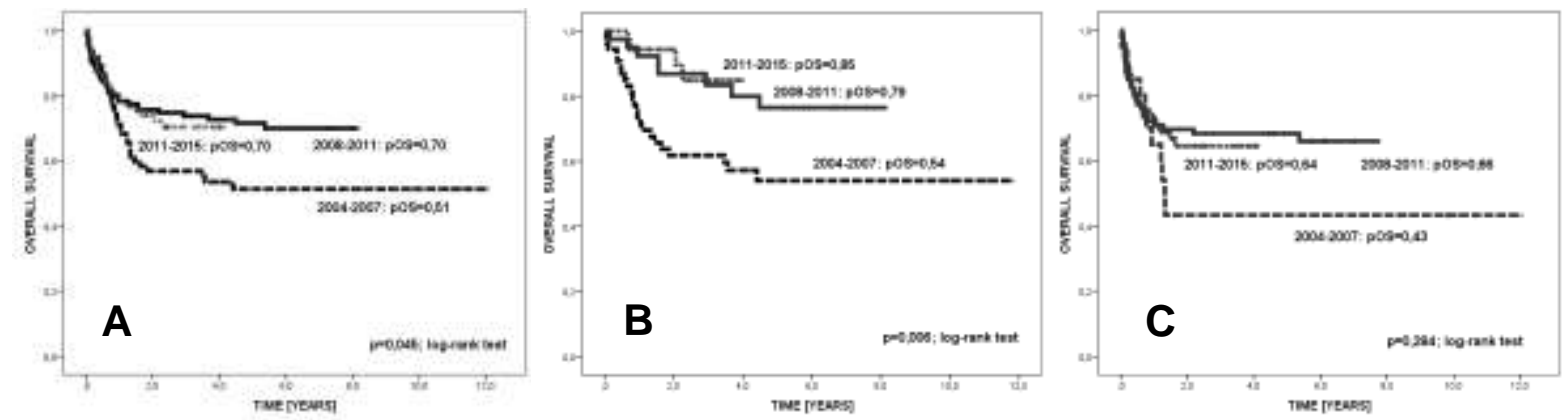

Fig. 1. Probability of overall survival (pOS) after hematopoietic stem cell transplantation (HSCT) with respect to period of therapy: (A) for all patients; (B) after auto-HSCT; (C) after allo-HSCT

Ryc. 1. Prawdopodobieństwo przeżycia (pOS) po trans-plantacji komórek hematopoetycznych w zależności od okresu terapii: (A) taczne, (B) auto-HSCT, (C) allo-HSCT

from this part of our country. Nowadays, all types of hematopoietic stem cell transplantations are being performed in our department: autologous and allogeneic, from matched family donors and from haploidentical donors, from matched and mismatched unrelated donors. All available stem cell sources were used for transplants in our center: peripheral blood, bone marrow and cord blood, both from national and international registries.

Current results of HSCT are dependent mainly on primary diagnosis, clinical stage or grade and previous therapy. The best results were obtained for patients with non-Hodgkin lymphoma and non-malignant diseases, while the worst for patients with solid tumors. Therapy failure was related to relapse after autologous transplants (mainly in patients with solid tumors) and infections complicating graft-versus-host disease after allogeneic transplants, especially in patients with leukemia. Nevertheless, presented results are comparable with those obtained by a large variety of European transplant centers, cooperating within EBMT (European Blood and Marrow Transplantation Group) as well as within CIBMTR (Center for International Blood and Marrow Transplant Research) registry [8,9]. Current improvement in HSCT outcome is dependent on both very good donor match and multidirectional and interdisciplinary supportive care. In the meantime, new therapeutic, diagnostic and supportive care modalities have been introduced in our center [10-12].

The improvement in outcome over the period of first 12 years from the setting of the transplant center shows growing experience and abilities of transplant team, both doctors and nurses. "The learning curve" of patients in our transplant center quickly showed results comparable with EBMT and CIBMTR centers. This is a valuable achievement since nowadays more and more patients with more complex diagnoses are qualified for transplantation, such as multiple-relapsed patients or those with advanced disease or co-existing comorbidities. It is an international trend that more and more patients are qualified for the second and subsequent transplant.

New treatment modalities, such as targeted therapy, caused significant changes in some indications for transplant. Introduction of tyrosine kinase inhibitors (TKI) such as imatinib and second generation TKIs resulted in rapid decline in number of transplants in chronic myeloid leukemia. On the other hand, more children with primary immunodeficiences are qualified for transplantation, what is evidence of progress in interdisciplinary co-operation and acceptance of transplantation among immunologists, as well as specialists in inborn disorders.

Over this period we also faced an international trend in increase of transplants from unrelated donors with a number of HSCTs exceeding the number of transplants from sibling donors. With increase in the number of donors in Polish registries over 750 thousands, nowadays most of our donors are Polish unrelated donors. However, even with high resolution typing of HLA (Human Leukocyte Antigens) and better donor match, the risk of GVHD is higher in case of transplants performed from unrelated donors than sibling donors; this might lead to an increase in the risk of other complications such as life-threatening infections. Thus, it is difficult to indicate if transplants 
from unrelated donors improve the results of overall survival. Still, the number of patients with transplantrelated mortality is too high, and there is an international need in improving supportive therapy for transplanted patients.

In summary, the presented results of HSCT obtained in our center are comparable with those from other international registries and centers. The transplant center in Bydgoszcz is well recognized in Europe. Two large international programs were coordinated in the department: pediatric sibling donors study and EBV-driven PTLD (post-transplant lymphoproliferative disorder) program $[10,13]$. The center is an active member of European Society of Blood and Marrow Transplantation (EBMT), and international program of European Conference on Infections in Leukemia and Stem Cell Transplantation (ECIL).

\section{ACKNOWLEDGEMENTS}

We thank physicians from the Department of Pediatric Hematology and Oncology at the Jurasz University Hospital of Bydgoszcz for their continuous support for transplant center, and the nursing staff of the Pediatric Transplant Team for their outstanding support and care of the patients.

\section{REFERENCES}

1. Gratwohl A, Pasquini MC, Aljurf M, Atsuta Y, Baldomero H, Foeken L, Gratwohl M, Bouzas LF, Confer D, Frauendorfer K, Gluckman E, Greinix H, Horowitz M, Iida M, Lipton J, Madrigal A, Mohty M, Noel L, Novitzky N, Nunez J, Oudshoorn M, Passweg J, van Rood J, Szer J, Blume K, Appelbaum FR, Kodera Y, Niederwieser D; Worldwide Network for Blood and Marrow Transplantation (WBMT). One million haemopoietic stem-cell transplants: a retrospective observational study. Lancet Haematol. 2015; 2(3): e91e100.

2. Passweg JR, Baldomero H, Bader P, Bonini C, Cesaro S, Dreger P, Duarte RF, Dufour C, Kuball J, Farge-Bancel D, Gennery A, Kröger N, Lanza F, Nagler A, Sureda A, Mohty M. Hematopoietic stem cell transplantation in Europe 2014: more than 40000 transplants annually. Bone Marrow Transplant. 2016 Feb 22. doi: 10.1038/bmt.2016.20 (Epub ahead of print).

3. Biuletyn informacyjny Poltransplant. Warszawa, 2015;23(1): 76-84.
4. Styczyński J, Dębski R, Krenska A, et al. Transplantacje komórek hematopoetycznych w świetle 5-letnich doświadczeń. Med Biol Sci, 2008; 22 (3): 157-163.

5. Gmerek A, Styczyński J, Krenska A, et al. Pneumonia in hematopoietic stem cell recipients during early posttransplant period. Med Biol Sci, 2009; 23 (3): 39-43.

6. Styczyński J, Gil L. Prevention of infectious complications in pediatric HSCT. Bone Marrow Transplant, 2008; 42 (suppl 2): S77-S81.

7. Styczynski J, Reusser P, Einsele H, et al. Management of herpes simplex, varicella-zoster and Epstein-Barr virus infection in patients with hematological malignancies and after stem cell transplantation. Guidelines from the Second European Conference on Infections in Leukemia. Bone Marrow Transplant, 2009; 43: 757-770

8. Gratwohl A, Sureda A, Baldomero H, Gratwohl M, Dreger P, Kröger N, Ljungman P, McGrath E, Mohty M, Nagler A, Rambaldi A, de Elvira CR, Snowden JA, Passweg J, Apperley J, Niederwieser D, Stijnen T, Brand R. Economics and outcome after hematopoietic stem cell transplantation: a retrospective cohort study. EBioMedicine. 2015;2(12):2101-9.

9. Pasquini $\mathrm{MC}$, Zhu $\mathrm{X}$. Current use and outcome of hematopoietic stem cell transplantation: CIBMTR Summary Slides, 2015. Available at: http://www.cibmtr.org.

10. Styczynski J, Gil L, Tridello G, Ljungman P, Donnelly JP, van der Velden W, Omar H, Martino R, Halkes C, Faraci M, Theunissen K, Kalwak K, Hubacek P, Sica S, Nozzoli C, Fagioli F, Matthes S, Diaz MA, Migliavacca M, Balduzzi A, Tomaszewska A, Camara Rde L, van Biezen A, Hoek J, Iacobelli S, Einsele H, Cesaro S. Response to rituximab-based therapy and risk factor analysis in Epstein Barr Virus-related lymphoproliferative disorder after hematopoietic stem cell transplant in children and adults: a study from the Infectious Diseases Working Party of the European Group for Blood and Marrow Transplantation. Clin Infect Dis. 2013;57:794-802.

11. Czyzewski K, Debski R, Krenska A, Wysocki M, Styczynski J. Palifermin in children undergoing autologous stem cell transplantation: a matched-pair analysis. Anticancer Res. 2014;34:7379-7382.

12. Groll AH, Castagnola E, Cesaro S, Dalle JH, Engelhard D, Hope W, Roilides E, Styczynski J, Warris A, Lehrnbecher T. Fourth European Conference on Infections in Leukaemia (ECIL-4): guidelines for diagnosis, prevention, and treatment of invasive fungal diseases in paediatric patients with cancer or allogeneic haemopoietic stem-cell transplantation. Lancet Oncol. 2014;15:e327-40.

13. Styczynski J, Balduzzi A, Gil L, Labopin M, Hamladji RM, Marktel S, Yesilipek MA, Fagioli F, Ehlert K, Matulova M, Dalle JH, Wachowiak J, Miano M, Messina 
C, Diaz MA, Vermylen C, Eyrich M, Badell I, Dreger P, Gozdzik J, Hutt D, Rascon J, Dini G, Peters C. Risk of complications during hematopoietic stem cell collection in pediatric sibling donors: a prospective European Group for Blood and Marrow Transplantation Pediatric Diseases Working Party study. Blood. 2012;119:29352942.
Address for correspondence: prof. dr hab. n. med. Jan Styczyński Katedra Pediatrii, Hematologii i Onkologii Collegium Medicum im. L. Rydygiera w Bydgoszczy Uniwersytet Mikołaja Kopernika

ul. Curie-Skłodowskiej 9 85-094 Bydgoszcz

e-mail: jstyczynski@cm.umk.pl

tel: (52) 5854860

fax: (52) 5854867

Received: 31.03.2016

Accepted for publication: 10.06.2016 